\title{
Effect of Plant Growth Retardants on Growth, Flowering and Yield of Chrysanthemum (Chrysanthemum Morifolium Ramat.) cv. IIHR-6
}

\author{
Mital Vaghasia ${ }^{1}$, N. D. Polara ${ }^{2 *}$ \\ ${ }^{1}$ M.Sc. (Horticulture) Student, Department of Horticulture, College of Agriculture, Junagadh Agricultural University, Junagadh (Gujarat), INDIA \\ ${ }^{2}$ Associate Professor, Department of Horticulture, College of Agriculture, Junagadh Agricultural University, Junagadh (Gujarat), INDIA \\ *Correspondence (Email): \\ ndpolara@jau.in
}

\begin{abstract}
The present experiment was conducted on chrysanthemum (Chrysanthemum morifolium Ramat.) cv. IIHR-6 at Jambu Vadi Farm, College of Agriculture, JAU, Junagadh during winter season of 2013-14 under South Saurashtra agro climatic condition. The experiment was laid out in Randomized Block Design with Factorial concept with two time of spray viz., spray at 30 days after transplanting $\left(\mathrm{S}_{1}\right)$ and spray at 60 days after transplanting $\left(\mathrm{S}_{2}\right)$ and six treatment of plant growth retardants viz., $\mathrm{MH} 500 @ \mathrm{mg} \mathrm{l}^{-1}\left(\mathrm{P}_{1}\right), \mathrm{MH} 700 @ \mathrm{mg} \mathrm{l}^{-1}$ $\left(\mathrm{P}_{2}\right)$, CCC @ $2000 \mathrm{mg} \mathrm{l}^{-1}\left(\mathrm{P}_{3}\right), \mathrm{CCC} @ 2500 \mathrm{mg} \mathrm{l}^{-1}\left(\mathrm{P}_{4}\right)$, PCB @ $0.4 \mathrm{ml} \mathrm{l}^{-1}\left(\mathrm{P}_{5}\right)$, PCB @ $0.5 \mathrm{ml} \mathrm{l}^{-1}\left(\mathrm{P}_{6}\right)$ were sprayed including control $\left(\mathrm{P}_{7}\right)$. The effect of different time of sprays and plant growth retardants on growth, flowering and yield of chrysanthemum cv. 'IIHR-6' were found significant. The vigorous growth in terms of plant height at 90 DAT $(52.65 \mathrm{~cm})$ and at the time of final harvest $(63.34 \mathrm{~cm})$ was noticed the highest in control $\left(\mathrm{P}_{7}\right)$ treatment while, the number of branches per plant at 90 DAT (28.80) and at the time of final harvest 34.89), plant spread in N - S (52.15 cm and $60.78 \mathrm{~cm})$ and E - W direction $(53.25$ and $62.45 \mathrm{~cm})$ at 90 DAT and at time of final harvest, respectively; fresh weight of plant (317.55 g) and dry weight of plant (35.87 g) recorded maximum under plant receiving $\mathrm{MH} @ 700 \mathrm{mg} \mathrm{l}^{-1}\left(\mathrm{P}_{2}\right)$. Consequently, these plants produced early flowers (70.94 days), took minimum days for 50 per cent flowering (101.16 days) with maximum flowering span (46.36 days), flower diameter $(6.33 \mathrm{~cm})$, shelf life (5.00 days) of flower as well as vase life (9.05 days) of flower. The yield of flowers (13.43 $\mathrm{t}$ ha $\left.{ }^{-1}\right)$ also produced maximum in these treatment. Interaction between different time of spray and plant growth retardants was found to be non significant in case of growth, flowering and yield of flowers, except diameters of flower. Economics of chrysanthemum indicated that the plant sprayed at 30 days after transplanting $\left(\mathrm{S}_{1}\right)$ and treated with $\mathrm{MH} @ 700 \mathrm{mg} \mathrm{l}^{-1}\left(\mathrm{P}_{2}\right)$ found most remunerative as they gave highest net returns (Rs. 208980) with maximum Benefit Cost Ratio (1:4.50). It can be concluded that the foliar application of $\mathrm{MH} @ 700 \mathrm{mg} \mathrm{l}^{-1}$ at 30 days after transplanting proved superior in terms of growth, flowering, flower yield and more economical as compared to all other growth retardants treatments.
\end{abstract}

Key words: Growth retardants, time of spray, flower yield, chrysanthemum

Source of Support: None, No Conflict of Interest: Declared

This article is is licensed under a Creative Commons Attribution-NonCommercial 4.0 International License.

Attribution-NonCommercial (CC BY-NC) license lets others remix, tweak, and build upon work non-commercially, and although the new works must also (CC) (5) acknowledge \& be non-commercial.

\section{INTRODUCTION}

Today with the advancement of technology, grower's main objectives in flower crop is perfection in the form of plants in the quality of flowers and increase in the flower production. Chrysanthemum, the golden flower is derived from two greek word (Chryos meaning golden and anthus meaning flower), is one of the most beautiful and perhaps the oldest flowering plants commercially grown in different parts of the world. Chrysanthemum botanically known as (Chrysanthemum morifolium Ramat.), belongs to the family Asteraceae, it is believed to have originated from China 
(Carter, 1980). It is commonly known as Queen of East, Autumn Queen and Guldaudi. It is important for both as cut flower and as potted plant in the international market. In India, it has been recognized as one among the five important commercially potential flower crops. It is grown commercially for cut and loose flowers as well as pot plant. It is grown in many parts of the world. Owing to its excelling beauty and economic values. The plant grows erect and tall making it suitable for border planting, loose flower, or as cut flower. It is also grown in pots for flower shows. The utility and popularity of the chrysanthemum have increased greatly with the technique of year-round blooming habit based on the research in the field of photoperiodic and genetics. It is preferred practically due to its vast range of shapes and sizes of flowers, brilliance of colour tones, long lasting florets life, and diversity of height and growth habit of the plant, exceptionally hardy nature, relative ease to grow all the year round and versatility of use. In india it is grown in 2.18 lakh hectares with the production of 14.21 lakh million tones production of loose flowers and 75,413 million numbers of cut flowers. (Anonymous, 2013). Now a days various chemicals are being tried for controlling growth and flowering of chrysanthemum with a view to have compact plants and also to stretch out or retard the rate of plant growth. Exogenously applied growth substances produce their effect through the alteration in endogenous hormones, thus modifying the growth and development of plants. In recent years scientist have given due attention to the idea of regulating plant growth as third most important factors in improving the growth, yield and quality with the application of plant growth regulators by various ways. These substances modify the plant physiological processes within the plant, which ultimately affect the growth, yield and quality. Growth retardants treatments are increasingly studied with greater number of flowers and also to hasten or delay flowering according to the needs of growers in chrysanthemum (Dutta et al. 1993, Yewale et al. 1997). Regulation of flowering, through growth retardants has immense practical value. Timing of the peak flowering to coincide with the time of greatest demand and generally modifying the flowers sequence to avoid peak production at about the time would confer great advantage to the grower and consumers. Paclobutrazol results in retardation of vegetative growth and divers of assimilates to reproductive growth, giving increased growth potentional and 2chloroethyl - trimethyl ammonium chloride or Cycocel (CCC) and Maleic Hydrazide (MH) have been found to retard plant height by reducing intermodal length and also simultaneously it reduces the formation of lateral shoots thereby plant produces more number of flower bearing shoot in chrysanthemum (Yewale et al. 1997, Navale et al. 2010 and Singh, 2001). Paclobutrazol reduces plant height by suppressing the apical dominance, increases the main and secondary branches thereby increasing the flower number with reduction of flower diameter (Henrsel, 1985). Therefore, the experiment was undertaken to find out effect of plant growth retardants on growth, flowering and yield of chrysanthemum.

\section{Materials AND Methods}

The field experiment was conducted to study the effect of plant growth retardants on growth, flowering and yield of chrysanthemum cv. IIHR-6 at College of Agriculture, JAU, Junagadh during winter season of 2013-14. Junagadh is situated at $21.5^{\circ} \mathrm{N}$ latitude and $70.5^{\circ} \mathrm{E}$ longitudes with an altitude of 60 meters above the mean sea level, on the western side at the foothill of mountain Girnar. The experiment was laid out in Randomized Block Design with Factorial concept with two time of spray viz., spray at 30 days after transplanting $\left(\mathrm{S}_{1}\right)$ and spray at 60 days after transplanting $\left(\mathrm{S}_{2}\right)$ and six treatment of plant growth retardants viz., $\mathrm{MH} 500 @ \mathrm{mg} \mathrm{l}^{-1}\left(\mathrm{P}_{1}\right), \mathrm{MH} 700 @ \mathrm{mg} \mathrm{l}^{-1}\left(\mathrm{P}_{2}\right), \mathrm{CCC}$ @ $2000 \mathrm{mg} \mathrm{l}^{-1}\left(\mathrm{P}_{3}\right), \mathrm{CCC} @ 2500 \mathrm{mg} \mathrm{l}^{-1}\left(\mathrm{P}_{4}\right), \mathrm{PCB} @ 0.4 \mathrm{ml} \mathrm{l}^{-1}\left(\mathrm{P}_{5}\right), \mathrm{PCB} @ 0.5 \mathrm{ml} \mathrm{l}^{-1}\left(\mathrm{P}_{6}\right)$ were sprayed including control $\left(\mathrm{P}_{7}\right)$. Cuttings were prepared from the mother block maintained in the polyhouse of Department of Horticulture, College of Agriculture, Junagadh. Herbaceous cuttings of 20-25 cm were prepared and planted in the flat bed in polyhouse. Fifty five days old, healthy free from pest and disease rooted suckers were transplanted in each plot at 45 x $45 \mathrm{~cm}$ spacing during September 2013. Well decomposed farmyard manure was incorporated uniformly in the soil during preparation of soil at the rate of $10 \mathrm{t} \mathrm{ha}^{-1}$ and mixed well. Fertilizers were applied @ $120 \mathrm{~kg}$ nitrogen (Urea), $60 \mathrm{~kg}$ of phosphorus (Single Super Phosphate) and $60 \mathrm{~kg}$ potash (Muriate of Potash) per hectare. Full dose of phosphorus and potash was applied uniformly as a basal dose to all the plots and half dose of nitrogen was applied at 10 days after transplanting and remaining half dose of nitrogen was given at 30 days after transplanting. Foliar application of each growth retardants was given as per treatments, first spray given on $30^{\text {th }}$ October, 2013 i.e. 30 DAT and second at 30 ${ }^{\text {th }}$ November, 2013 i.e. 60 DAT. Irrigation was given before fertilization to the crop for maintaining soil moisture.

\section{RESULTS AND DISCUSSION}

\section{Effect on growth parameters}

The results from Table 1 revealed that growth parameter viz., number of branches and plant spread of the plant were maximum in chrysanthemum cv. 'IIHR-6' when sprayed at 30 days after transplanting $\left(\mathrm{S}_{1}\right)$ while, plant height was maximum when sprayed at 60 days after transplanting $\left(S_{2}\right)$. Increase in number of branches in $S_{1}$ treatments might be due to stimulation of branching and production of number of nodes possibly attributed to the breakage of 
apical dominance and thereby settings up of balance as well as enhanced differentiation of internodes. Similar results were reported earlier by Dani et al. (2010) in African marigold, Joshi and Reddy (2006) in China aster. Among all treatments, MH $700 \mathrm{mg} \mathrm{l}^{-1}$ observed maximum reduction of plant height. The reduction in plant height due to lowering of the auxin content and acts antagonistically to auxin thus completely suppresses the apical dominance by inhibiting the cell division on the apical meristem and thereby resulting in the reduction of the plant height. The results are in agreement with the findings of Sharma et al. (1995) and Kumar and Ughreja (1998) who obtained considerable growth reduction in chrysanthemum and Khandelwal et al. (2003) in marigold and Vasoya (2012) in gaillardia with MH. Cycocel (CCC) caused significant reduction in plant height as it is seen from the Table 1.

Table 1: Effect of growth retardants on growth parameters of chrysanthemum cv. IIHR-6

\begin{tabular}{|c|c|c|c|c|c|c|c|c|c|c|}
\hline \multirow[t]{2}{*}{ Treatments } & \multicolumn{2}{|c|}{$\begin{array}{l}\text { Plant height } \\
\text { (cm) }\end{array}$} & \multicolumn{2}{|c|}{$\begin{array}{l}\text { Plant spread } \\
\text { in N-S }(\mathrm{cm} 2)\end{array}$} & \multicolumn{2}{|c|}{$\begin{array}{l}\text { Plant spread } \\
\text { in E-W }(\mathrm{cm} 2)\end{array}$} & \multicolumn{2}{|c|}{$\begin{array}{c}\text { No. of branches } \\
\text { per plant }\end{array}$} & \multirow[t]{2}{*}{$\begin{array}{l}\text { Fresh weight } \\
\text { of plant (g) }\end{array}$} & \multirow[t]{2}{*}{$\begin{array}{l}\text { Dry weight } \\
\text { of plant (g) }\end{array}$} \\
\hline & 90 DAT & At harvest & 90 DAT & At harvest & 90 DAT & At harvest & 90 DAT & At harvest & & \\
\hline \multicolumn{11}{|c|}{ - } \\
\hline $\mathrm{S}_{1}-30 \mathrm{DAT}$ & 46.85 & 56.91 & 49.56 & 57.47 & 50.74 & 59.19 & 26.45 & 32.84 & 300.99 & 32.54 \\
\hline $\mathrm{S}_{2}-60 \mathrm{DAT}$ & 49.41 & 59.76 & 47.16 & 54.31 & 48.40 & 56.07 & 25.06 & 30.51 & 278.66 & 30.65 \\
\hline S.Em. \pm & 0.77 & 0.83 & 0.71 & 0.89 & 0.70 & 0.92 & 0.41 & 0.64 & 4.48 & 0.57 \\
\hline C.D. at $5 \%$ & 2.25 & 2.43 & 2.06 & 2.58 & 2.04 & 2.69 & 1.19 & 1.87 & 13.02 & 1.65 \\
\hline \multicolumn{11}{|l|}{ Plant Growth Retardants (P) } \\
\hline $\mathrm{P}_{1}-\mathrm{MH}-500 \mathrm{mg} \mathrm{l}^{-1}$ & 46.00 & 56.00 & 50.32 & 58.15 & 52.19 & 60.00 & 27.26 & 33.61 & 299.11 & 33.15 \\
\hline $\mathrm{P}_{2}-\mathrm{MH}-700 \mathrm{mg} \mathrm{l}^{-1}$ & 44.48 & 54.72 & 52.15 & 60.78 & 53.25 & 62.45 & 28.80 & 34.89 & 317.55 & 35.87 \\
\hline $\mathrm{P}_{3}-\mathrm{CCC}_{-}-2000 \mathrm{mg} \mathrm{l}^{-1}$ & 46.75 & 56.75 & 47.24 & 54.80 & 48.24 & 56.46 & 25.59 & 30.60 & 289.28 & 31.72 \\
\hline $\mathrm{P}_{4}-\mathrm{CCC}-2500 \mathrm{mg} \mathrm{l}^{-1}$ & 47.06 & 57.06 & 49.98 & 57.81 & 50.98 & 59.81 & 26.31 & 32.78 & 298.36 & 33.00 \\
\hline $\mathrm{P}_{5}-\mathrm{PCB}-0.4 \mathrm{ml} \mathrm{l}^{-1}$ & 49.48 & 59.98 & 45.05 & 52.30 & 46.55 & 53.97 & 23.14 & 28.77 & 267.81 & 27.38 \\
\hline $\mathrm{P}_{6}-\mathrm{PCB}-0.5 \mathrm{ml} \mathrm{l}^{-1}$ & 50.50 & 60.50 & 46.78 & 53.08 & 47.78 & 54.75 & 25.04 & 31.33 & 284.85 & 30.33 \\
\hline P7 - Control (Water spray) & 52.65 & 63.34 & 47.00 & 54.31 & 48.00 & 55.98 & 24.16 & 29.75 & 271.82 & 29.72 \\
\hline S.Em. \pm & 1.64 & 1.77 & 1.50 & 1.88 & 1.49 & 1.96 & 0.87 & 1.36 & 9.50 & 1.20 \\
\hline C.D. at $5 \%$ & 4.78 & 5.15 & 4.37 & 5.46 & 4.33 & 5.70 & 2.53 & 3.96 & 27.63 & 3.50 \\
\hline \multicolumn{11}{|l|}{ Interaction $(\mathrm{S} \times \mathrm{P})$} \\
\hline S.Em. \pm & 2.32 & 2.50 & 2.13 & 2.66 & 2.11 & 2.77 & 1.23 & 1.93 & 13.44 & 1.70 \\
\hline C.D. at $5 \%$ & NS & NS & NS & NS & NS & NS & NS & NS & NS & NS \\
\hline C.V.\% & 8.36 & 7.43 & 7.62 & 8.24 & 7.36 & 8.33 & 8.27 & 10.53 & 8.03 & 9.32 \\
\hline
\end{tabular}

The reduction in plant height due to the anti-auxin activity, distributed carbohydrate metabolism and inhibition of cell division and elongation of apical meristem might contribute to growth reduction and shortening of internodes in plant treated with CCC. Reduced plant height due to CCC treatment was also reported earlier by Talukdar and Paswan (1997) and Navale et al. (2010) in chrysanthemum. The result also indicated that the reduction of plant height was obtained with treatment of PCB. The reason for reduction in plant height due to PCB treatments might be attributed to the inhibition of gibberellins synthesis which caused reduction in stem elongation resulting in restricted growth of internodes. Corroboratory results have been obtained by Muhammad et al. (1997), Yewale et al. (1998a) and Kulkarni and Reddy (2003) in chrysanthemum.

All the chemical treatments significantly increase the plant spread in both the directions ( $\mathrm{N}-\mathrm{S}$ and $\mathrm{E}-\mathrm{W})$. Increased in the plant spread may be due to suppression of apical dominance that produced greater number of main and lateral branches, resulting in increased plant spread in both the directions. $\mathrm{MH}$ at all the concentrations significantly increased the plant spread in both the directions because of suppression in apical dominance that produced greater number of main and secondary branches. These finding are in accordance with the findings of Meher et al. (1999) and Navale et al. (2010) in chrysanthemum.

$\mathrm{MH}$ at $700 \mathrm{mg} \mathrm{l}^{-1}$ increased the number of branches which induces the lateral growth and ultimately increases the branches. These findings are supported by Dutta and Ramdas (1998), Kumar and Ughreja (1998) and Meher et al. (1999) in chrysanthemum. Considering the effect of CCC, number of secondary shoots was significantly increased in the number of internodes and increased photosynthetic efficiency of the plant due to an increase in chlorophyll. A similar effect of CCC on number of branches was also observed by Dhiman et al. (2003) in chrysanthemum. Increase in fresh weight and dry weight of plant with $\mathrm{MH}$ and CCC treatments concentration might be due to accumulation of more metabolite and also availability of reserve food for the reproductive growth. Similar results were also obtained earlier by Dutta and Ramdas (1998) and Moond et al. (2006) in chrysanthemum.

The interaction effect of different time of spray and plant growth retardants was found non significant in all the growth parameters viz., plant height, plant spread, number of branches per plant, fresh weight and dry weight of plant. 


\section{Effect on flowering and yield parameters}

All the treatment of growth retardants differed significantly with respect to days to first flower bud appearance and first flowering, days to 50 per cent flowering were significantly minimum when plant was sprayed at $30 \mathrm{DAT}\left(\mathrm{S}_{1}\right)$ which accumulated of vegetative bud into the reproductive bud. The treatments of $\mathrm{MH}$ and CCC significantly delayed bud formation as compared to control. Maximum delay in bud formation was observed with $\mathrm{MH}_{700} \mathrm{mg} \mathrm{l}^{-1}$ treatment. The delay in flower bud formation may be due to reduction in the flower bud development and inhibition of GA biosynthesis by the applied chemicals. Similar finding were also obtained by Dutta and Ramdas (1998), Kumar and Ughreja (1998) and Navale et al. (2010) in chrysanthemum. In the present investigation, response of different treatments to days required for opening of first flower after transplanting differed significantly. The delay due to $\mathrm{MH}$ is as a result of growth inhibition. Higher concentration of $\mathrm{MH}$ delays flower opening because of its action as an antiauxin, which is necessary for increase or decrease of the tissue favouring the flower formation and their development. Similar results were obtained in chrysanthemum sprayed with MH by Khandelwal et al. (2003) in African marigold and Navale et al. (2010) in chrysanthemum.

Data presented in Table 2 revealed that the treatment of $\mathrm{MH}$ and CCC significantly increased the flowering span of chrysanthemum. This might be due to availability of more photosynthetic for the longer time, so as to prolong reproductive phase. Increase in weight of flower with $\mathrm{MH}$ and CCC treatments concentration might be due to accumulation of more metabolite and also availability of reserve food for the reproductive growth. This result is in conformity with the findings of Dutta and Ramdas (1998) and Moond et al. (2006) in chrysanthemum.

In yield parameters the results indicated that number of flower per plant and flower yield was recorded maximum under plant spraying at 30 DAT $\left(\mathrm{S}_{1}\right)$. The more number of branches and maximum plant spread in this treatment had accumulated more carbohydrates through photosynthesis and were directly used for increasing the number of flowers and flower yield. In the present investigation maximum number of flowers per plant and flower yield was observed with MH $700 \mathrm{mg} \mathrm{l}^{-1}$ (Table 2).

Table 2: Effect of growth retardants on flowering and flower yield of chrysanthemum cv. IIHR-6

\begin{tabular}{|c|c|c|c|c|c|c|c|c|c|}
\hline Treatments & $\begin{array}{c}\text { Days } \\
\text { required to } \\
\text { first flower } \\
\text { bud }\end{array}$ & $\begin{array}{c}\text { Days } \\
\text { required for } \\
\text { opening of } \\
\text { first flower }\end{array}$ & $\begin{array}{c}\text { Days to } 50 \\
\text { per cent } \\
\text { flowering }\end{array}$ & \begin{tabular}{|c|} 
Flowering \\
span \\
(days)
\end{tabular} & $\begin{array}{c}\text { Fresh } \\
\text { weight of } \\
\text { flower per } \\
\text { plant (g) }\end{array}$ & $\begin{array}{c}\text { Number of } \\
\text { flowers per } \\
\text { plant }\end{array}$ & $\begin{array}{c}\text { Number of } \\
\text { flowers per } \\
\text { plot }\end{array}$ & $\begin{array}{l}\text { Yield of } \\
\text { flowers per } \\
\text { plot (kg) }\end{array}$ & $\begin{array}{l}\begin{array}{l}\text { Yield of } \\
\text { flowers } \\
\text { (t ha-1) }\end{array}\end{array}$ \\
\hline \multicolumn{10}{|l|}{ Time of sprays (S) } \\
\hline$S_{1}-30$ DAT & 69.01 & 75.48 & 106.24 & 43.26 & 102.73 & 30.89 & 741.34 & 2.52 & 10.88 \\
\hline $\mathrm{S}_{2}-60 \mathrm{DAT}$ & 72.60 & 80.23 & 111.44 & 38.53 & 95.34 & 28.78 & 690.64 & 2.39 & 9.59 \\
\hline S.Em. \pm & 1.03 & 1.40 & 1.32 & 0.73 & 2.06 & 0.62 & 14.80 & 0.04 & 0.18 \\
\hline C.D. at $5 \%$ & 3.00 & 4.06 & 3.85 & 2.12 & 6.00 & 1.79 & 43.04 & 0.11 & 0.52 \\
\hline \multicolumn{10}{|l|}{ Plant Growth Retardants (P) } \\
\hline $\mathrm{P}_{1}-\mathrm{MH}-500 \mathrm{mg} \mathrm{l}^{-1}$ & 67.07 & 73.62 & 102.58 & 41.39 & 110.59 & 31.87 & 764.80 & 2.59 & 11.71 \\
\hline $\mathrm{P}_{2}-\mathrm{MH}-700 \mathrm{mg} \mathrm{l}^{-1}$ & 64.51 & 70.94 & 101.16 & 46.36 & 120.46 & 33.62 & 806.80 & 2.64 & 13.43 \\
\hline $\mathrm{P}_{3}-\mathrm{CCC}-2000 \mathrm{mg} \mathrm{l}^{-1}$ & 69.65 & 74.24 & 106.57 & 40.07 & 98.87 & 29.50 & 707.88 & 2.40 & 10.06 \\
\hline $\mathrm{P}_{4}-\mathrm{CCC}-2500 \mathrm{mg} \mathrm{l}^{-1}$ & 71.70 & 79.88 & 113.50 & 43.15 & 103.39 & 30.04 & 720.84 & 2.56 & 10.91 \\
\hline $\mathrm{P}_{5}-\mathrm{PCB}-0.4 \mathrm{ml} \mathrm{l}^{-1}$ & 76.75 & 83.70 & 118.72 & 37.89 & 93.43 & 27.12 & 650.84 & 2.28 & 6.83 \\
\hline $\mathrm{P}_{6}-\mathrm{PCB}-0.5 \mathrm{ml} \mathrm{l}^{-1}$ & 72.40 & 80.76 & 109.65 & 39.25 & 80.17 & 28.79 & 690.96 & 2.39 & 9.78 \\
\hline P7 - Control (Water spray) & 73.54 & 81.84 & 109.69 & 38.19 & 86.33 & 27.91 & 669.80 & 2.36 & 8.93 \\
\hline S.Em. \pm & 2.19 & 2.96 & 2.81 & 1.55 & 4.38 & 1.31 & 31.40 & 0.08 & 0.38 \\
\hline C.D. at $5 \%$ & 6.37 & 8.62 & 8.16 & 4.50 & 12.72 & 3.80 & 91.31 & 0.22 & 1.11 \\
\hline \multicolumn{10}{|l|}{ Interaction $(\mathrm{S} \times \mathrm{P})$} \\
\hline S.Em. \pm & 3.10 & 4.19 & 3.97 & 2.19 & 6.19 & 1.85 & 44.41 & 0.11 & 0.54 \\
\hline C.D. at $5 \%$ & NS & NS & NS & NS & NS & NS & NS & NS & NS \\
\hline C.V.\% & 7.58 & 9.32 & 6.32 & 9.27 & 10.82 & 10.74 & 10.74 & 7.66 & 9.15 \\
\hline
\end{tabular}

This increase in number of flowers per plant might be due to increased number of branches which ultimately enhanced the flower production. Increase in flower yield might be due to reduced plant height by suppressing the apical dominance, increased the main and secondary branching, thereby increasing the flower number which ultimately resulted in increased yields of flowers. The results are in conformity with the findings of Navale et al. (2010), Dutta and Ramdas (1998), Sharma et al. (1995), Sen and Maharana et al. (1971) and Meher et al. (1999) in chrysanthemum.

The interaction effect between time of spray and plant growth retardants was found non significant with respect to flowering and yield parameters viz., days required for opening of first flower, days to 50 per cent flowering, flowering span, fresh weight of flower and yield parameters. Economics indicated that the plant sprayed at 30 days after transplanting $\left(\mathrm{S}_{1}\right)$ and sprayed with $\mathrm{MH} 700 \mathrm{mg} \mathrm{l}^{-1}\left(\mathrm{P}_{2}\right)$ were found most remunerative as they gave highest net returns with maximum Benefit Cost Ratio (BCR). These findings are in agreement with the reports of Navale et al. (2010) and Talukdar and Paswan (1997) in chrysanthemum; Khimani et al. (1994) and Makwana (1999) in gaillardia; Dani et al. (2010) in marigold; and Joshi and Reddy (2006) in China aster. 
Table 3: Economics of different treatments of growth retardants in chrysanthemum cv. IIHR-6

\begin{tabular}{|c|c|c|c|c|c|}
\hline Treatments & $\begin{array}{l}\text { Yield } \\
\text { (q/ha) }\end{array}$ & $\begin{array}{c}\text { Gross realization } \\
\left(\text { Rs. ha }^{-1}\right)\end{array}$ & $\begin{array}{c}\text { Total expenditure } \\
\left(\text { Rs. ha }{ }^{-1}\right)\end{array}$ & $\begin{array}{c}\text { Net realization } \\
\left(\text { Rs. ha }{ }^{-1}\right)\end{array}$ & $\begin{array}{c}\text { Cost: Benefit } \\
\text { ratio }\end{array}$ \\
\hline \multicolumn{6}{|l|}{ Time of sprays (S) } \\
\hline $\mathrm{S}_{1}-30 \mathrm{DAT}$ & 10.88 & 217600 & 60017 & 157583 & $1: 3.62$ \\
\hline $\mathrm{S}_{2}-60 \mathrm{DAT}$ & 9.59 & 191800 & 60017 & 131783 & $1: 3.19$ \\
\hline \multicolumn{6}{|l|}{ Plant Growth Retardants (P) } \\
\hline $\mathrm{P}_{1}-\mathrm{MH}-500 \mathrm{mg} \mathrm{l}^{-1}$ & 11.71 & 234200 & 59520 & 174680 & $1: 3.93$ \\
\hline $\mathrm{P}_{2}-\mathrm{MH}-700 \mathrm{mg} \mathrm{l}^{-1}$ & 13.43 & 268600 & 59620 & 208980 & $1: 4.50$ \\
\hline$P_{3}-C_{C C}-2000 \mathrm{mg} \mathrm{l}^{-1}$ & 10.06 & 201200 & 60265 & 140935 & $1: 3.33$ \\
\hline $\mathrm{P}_{4}-\mathrm{CCC}-2500 \mathrm{mg} \mathrm{l}^{-1}$ & 10.91 & 218200 & 60515 & 157685 & $1: 3.60$ \\
\hline $\mathrm{P}_{5}-\mathrm{PCB}-0.4 \mathrm{ml} \mathrm{l}^{-1}$ & 6.83 & 136600 & 59353 & 77247 & $1: 2.30$ \\
\hline $\mathrm{P}_{6}-\mathrm{PCB}-0.5 \mathrm{ml} \mathrm{l}^{-1}$ & 9.78 & 195600 & 59378 & 136222 & $1: 3.29$ \\
\hline $\mathrm{P}_{7}$ - Control (Water spray) & 8.93 & 178600 & 59267 & 119333 & $1: 3.01$ \\
\hline
\end{tabular}

Note: Selling price of flowers (Rs. 20 per $\mathrm{Kg}$ )

Urea: 304 Rs. per bag (50 kg), SSP: 357 Rs. per bag (50 kg) and MOP: 893 Rs. per bag (50 kg)

MH: 9.4 Rs. per g, CCC: 950 Rs. per 500g and PCB: 6000 Rs. per litre

\section{CONCLUSION}

The foliar spray of $\mathrm{MH} 700 \mathrm{mg} \mathrm{l}^{-1}$ at 30 days after transplanting recorded the highest number of branches, plant spread, fresh and dry weight of the plant, early flowering with maximum flower production. Same treatment also proved to be superior and more economical as compared to all other treatments in chrysanthemum cV. IIHR- 6 in winter season of South Saurashtra agro climatic condition.

\section{REFERENCES}

Anonymous (2010-11b). Director of Horticulture, Gujarat state, Gandhinagar.

Aswath, S., Narayana Gouda, J. V. and Anand Murthy, G. M. (1994). Effect of growth retardants on growth, flowering and nutrient content in china aster [Callistephus chinensis (L.) Nees.] cv. Powder paft mixed. J. Ornamental Hort., 2(1-2): 9-13.

Crafts, A. C., Currier, H. B. and Day, B. E. (1950). Response of several crop plants and weed to maleic hydrazide. Hilgardia, 20: 57-80.

Datta, J. P., Ramdas, S. and Khader, M. A. (1993). Regulation of flowering by growth regulators in chrysanthemum (Chrysanthemum indicum L.) cv. 'CO-1'. South Indian Hort., 41(5): 293-299.

Henrsel, J. W. (1985). Benzia new growth regulator for evergreen aza, Deutscher gontobnban, Institute for Zeirpflangenban, Melles Belgium. 29(37): 1742-1746.

Hugar, A. H. and Nalawadi, U. G. (1999). Effect of growth regulators on morphological characters, flower production and seed yield of gaillardia. Karnataka J. Agric. Sci., 12(1/4): 226-229.

Khandelwal, S. K., Jain, N. K. and Singh, P. (2003). Effect of growth retardants and pinching on growth and yield of African marigold. J. Ornamental Hort., 6(3): 271-273.

Khimani, R. A., Patil, A. A. and Kanamadi, V. C. (1994). Effect of growth retardants on growth and flower production of gaillardia (Gaillardia pulchella var.'Picta Fouger'). Floriculture Technology, Trades and Trends. Prakash, J. and Bhandari, K.R. (eds.), Oxford and IBH Publishing Co. Pvt. Ltd., New Delhi, pp. 119-121.

Kumar, K. P. (1987). Studies on the effect of nutrients and growth retardants on growth, flowering and quality of African marigold (Tagetes erecta L.). M.Sc. (Agri) Thesis, University of Agricultural Sciences, Bangalore.

Makwana, M. K. (1999). The effect of plant growth regulators on growth, yield and quality of gaillardia (Gaillardia pulchella) cv. 'Lorenziana'. M.Sc. (Agri.) thesis submitted to Gujarat Agricultural University, Sardar Krushinagar.

Narayanagouda, J. V. (1985). Investigation on horticultural practices in the production of China aster (Callistephus chinensis Nees.). Ph.D. Thesis, University of Agricultural Sciences, Bangalore.

Narayanagouda, J. V. and Jayanthi, R. (1991). Effect of cycocel and maleic hydrazide on growth and flowering of African marigold. Prog. Hort., 23(1-4): 114-118.

Parmar, A. S. and Singh, S. N. (1983). Effect of plant growth regulators on growth and flowering of marigold (Tagetes erecta). South Indian Hort., 31(1): 53 - 54.

Patel K. R. (1990). Effect of plant growth regulators on growth, flowering and flower yield of marigold (Tagetes erects L.) cv. 'Lemon'. M.Sc. (Agri.) thesis submitted to Gujarat Agricultural University, Sardar Krushinagar.

Patel, S. L. (1997). Effect of plant growth regulators on growth, flowering and flower yield of annual gaillardia (Gaillardia pulchella Foug.) var. 'Lorenziana'. M.sc (Agri.) Thesis submitted to Navsari Agricultural University, Navsari.

Radmacher W (1991). Gibberellins by N. Takahashi, B. O. Phiney and J. Macmillan.

Saiyad, M. Y., Jadav, R. G., Parmar, A. B. and Chauhan K. M. (2009). Effect of plant growth retardents and pinching on growth, flowering and yield of gaillardia (Gaillardia pulchella). Prajana J. pure and Applied Sci., 17: 55-57.

Sehrawat, S. K., Dahiya, D. S., Sukhbir Singh. and Rana, G. S. (2003). Effect of nitrogen and pinching on the growth, flowering and yield of marigold (Tagetes erecta L. ) cv. African Giant Double Orange. Haryana J. hort. Sci., 32(1/2):59-61.

Shanmugam, A. and Muthuswamy, S. (1974). Effect of CCC and TIBA on chrysanthemum. Indian J. Hort., 31: $370-374$.

Sharma, H. G., Verma Vijay Jain, L. S. and Tiwari, B. L. (1995). Effect of foliar application of some plant growth regulators on growth and flowering of chrysanthemum var. 'Move-in-carvin'. Orissa J. Hort., 23(1\&2): 61-64. 
Shreedhar, D. (1993). Effect of growth regulators on growth and flower yield of gailardia (Gaillardia pulchella fouger) cv. Khanabargi local. M.Sc. (Agri.) Thesis, University of Agricultural Sciences, Dharwad.

Singh, A. K. (2004). Growth and seed yield of African marigold as influenced by growth retarding chemicals. South Indian Hort., 52: 377-380.

Sunitha, H. M., Hunje Ravi, Vyakaranahal B. S. and Bablad H. B. (2007). Effect of pinching and growth regulators on plant growth, flowering and seed yield of African marigold (Tagetes erecta Linn.). J. Ornamental Hort., 10(2): 91-95.

Talukdar, M. C. and Paswan, L. (1997). Growth and flowering in chrysanthemum (Dendranthema grandiflorum Tzveley) cv. 'Maharaja' as influenced by GA3 and cycocel. Haryana J. Hort. Sci., 26(1-2): 55-57.

Weaver, R. J. (1972). "Plant Growth Substances in Agriculture”. W.H. Freeman and Company. San Francisco. pp. 106-179.

$$
\text { -- } 0 \text {-- }
$$

